University of Wollongong

Research Online

Faculty of Business - Papers (Archive)

Faculty of Business and Law

$1-1-2014$

Disclosure incentives, mandatory standards and firm communication in the IFRS adoption setting

Marvin Wee

University of Western Australia

Ann Tarca

University of Western Australia

Millicent M. Chang

University of Western Australia, mchang@uow.edu.au

Follow this and additional works at: https://ro.uow.edu.au/buspapers

Part of the Business Commons

Research Online is the open access institutional repository for the University of Wollongong. For further information contact the UOW Library: research-pubs@uow.edu.au 


\title{
Disclosure incentives, mandatory standards and firm communication in the IFRS adoption setting
}

\author{
Abstract \\ We investigate the content, timing and relevance of firms' narrative disclosure about the effects of IFRS \\ adoption in annual statutory financial statements and firm announcements to the stock exchange for 150 \\ large listed Australian firms in the three-year period surrounding adoption (which occurred from 1 January \\ 2005). We observe communication about changes in financial reports, even when the change relates to \\ accounting rather than economic events. We record more disclosure by firms experiencing an adverse \\ change in earnings, consistent with them being sensitive to signals about future earnings. When \\ economic performance is stronger, firms provide less discussion of the accounting effects of IFRS. We \\ also find the discussion of IFRS impact in both disclosure channels is value-relevant for firms with \\ relatively higher levels of disclosure, providing evidence of the usefulness of transition disclosures. The \\ Author(s) 2013. \\ Disciplines \\ Business

\section{Publication Details} \\ Wee, M., Tarca, A. \& Chang, M. (2014). Disclosure incentives, mandatory standards and firm \\ communication in the IFRS adoption setting. Australian Journal of Management, 39 (2), 265-291.
}




\title{
Disclosure Incentives, Mandatory Standards and Firm Communication in the IFRS Adoption Setting
}

\author{
by \\ Marvin Wee, Ann Tarca and Millicent Chang \\ UWA Business School, University of Western Australia, Australia
}

Corresponding author:

Marvin Wee, UWA Business School, M250, 35 Stirling Highway, Crawley, Western Australia 6009.

Email: Marvin.Wee@uwa.edu.au Tel: +61 864885860.

We thank Wendy Hsu, Tasha Grieve and Anthony $\mathrm{Vu}$ for their assistance in compiling the dataset. Helpful comments from Julie Cotter, Anne Gaeremynck, Gerry Gallery, John Holland, David Woodliff, Anne Wyatt and seminar participants at the Catholic University of Leuven, Monash University, Norges Handelshøyskole in Bergen, the Queensland University of Technology, the University of New South Wales and the University of Technology Sydney are gratefully acknowledged. We appreciate the very helpful suggestions of two anonymous reviewers and the editor.

Funding

This work was supported by the Accounting and Finance Association of Australia and New Zealand (AFAANZ) and the UWA Business School. 


\title{
Disclosure Incentives, Mandatory Standards and Firm Communication in the
} IFRS Adoption Setting

\begin{abstract}
:
We investigate the content, timing and relevance of firms' narrative disclosure about the effects of IFRS adoption in annual statutory financial statements and firm announcements to the stock exchange for 150 large listed Australian firms in the three year period surrounding adoption (which occurred from 1 January 2005). We observe communication about changes in financial reports, even when the change relates to accounting rather than economic events. We record more disclosure by firms experiencing an adverse change in earnings, consistent with them being sensitive to signals about future earnings. When economic performance is stronger, firms provide less discussion of the accounting effects of IFRS. We also find the discussion of IFRS impact in both disclosure channels is value relevant for firms with relatively higher levels of disclosure, providing evidence of the usefulness of transition disclosures.
\end{abstract}

JEL classification: M40, M41

\section{Keywords:}

International financial reporting standards (IFRS), AASB 1047, AASB 101, transition reconciliation, continuous disclosure regime, value relevance. 


\section{Disclosure Incentives, Mandatory Standards and Firm Communication in the IFRS Adoption Setting}

\section{Introduction}

We investigate the disclosures made by 150 Australian listed firms during the three year period surrounding adoption of International Financial Reporting Standards (IFRS) (from 1 January 2005). We make use of a specific capital market and financial reporting event, namely the adoption of International Financial Reporting Standards (IFRS), to examine the interaction of disclosure incentives arising from the institutional setting for financial reporting and those that can be linked to managers' incentives. The Australian institutional setting includes legally enforceable accounting standards with specific disclosure requirements, listing rules including the continuous disclosure requirements of the Australian Securities Exchange (ASX) and scrutiny by independent auditors and regulators, all of which can be expected to promote compliance and disclosure.

Nevertheless, the way firms respond to the mandatory requirements and the institutional setting will vary, reflecting their particular business and economic circumstances together with managers' incentives. On adoption of IFRS, firms had strong incentives to keep investors, analysts and other stakeholders informed during the transition process, to ensure the change to IFRS did not erroneously affect perceptions of a firm's prospects (Ernst and Young, 2003; Accountnet, 2004). However, disclosure also reflects managers' assessments of the costs and benefits of disclosure (Healy and Palepu, 2001), including such considerations as the perceived information value or usefulness to market participants.

The research questions we consider are as follows: What are the attributes and timing of firms' IFRS disclosures? To what extent do firms experiencing greater financial impact on earnings and equity from IFRS adoption provide more disclosure about the IFRS effects, given that IFRS is an accounting change, not a change in economic fundamentals? Do firms experiencing a larger negative impact on earnings and equity provide earlier disclosure and do they make greater use of more disclosure channels? Finally, is firm disclosure about IFRS impact beneficial, that is, is it value relevant for market participants? 
We find disclosure about the impact of IFRS increases over the three year period of our study, becoming more quantified in the adoption year as firms are better able to measure the impact of IFRS. On average, firms provide more disclosure about financial position, consistent with explaining IFRS effects on assets, liabilities and equity that carry forward and affect future financial ratios. Some firms made use of firm announcements to the ASX to communicate IFRS effects and there is more discussion of IFRS in the transition year compared to the adoption year. Firm announcements with discussion of IFRS effects were largely made after the financial year end date as part of the firm's earnings announcement.

We extend prior IFRS disclosure studies (Gallery et al. 2008; Kent and Stewart 2008; Palmer 2008) by considering a three year period, disclosure in financial statements and firm announcements to the ASX in 2005 and 2006, and several measures of disclosure (total, performance, position, qualitative, quantitative, and key impact items). We show that firm disclosure about the impact of IFRS on financial position and performance is associated with the change in earnings on transition (an accounting change) and the change in earnings in the first year of use of IFRS (an economic change).

Consistent with studies showing managers are sensitive to the nature of the news to be explained (Bloomfield 2008; Brown and Tucker, 2010; Matsumoto et al., 2011), we find disclosure about IFRS impact is linked to firm incentives to explain financial position and performance. For firms with 'bad news', that is firms that experience a fall in earnings in the adoption year, disclosure about IFRS effects in financial statements increases as the IFRS financial impact on earnings and equity is larger. Firm with 'good news' have relatively less incentive to provide explanations about IFRS effects. The relation between disclosure and IFRS impact is weaker for 'good news' firms and we find some evidence of less disclosure by firms experiencing a larger positive financial impact. The results suggest firms with poorer performance make relatively more use of disclosure about IFRS effects as they explain their results.

We also consider whether the disclosure provided is value relevant. Using models derived from Ohlson (1995), we examine the association between share price, book 
value of equity and earnings with IFRS impact disclosure. The latter includes both measures of the financial effect (the amount of difference between earnings and equity under AGAAP and IFRS) and measures of firm narrative disclosure about the impact.

By measuring disclosure in the adoption period, our results add to existing literature on the value relevance of IFRS compared to AGAAP (Goodwin et al. 2008; Clarkson et al. 2011; Chalmers et al. 2011). Goodwin et al. (2008) report that transition differences in earnings and equity are not value relevant in Australian firms. However, we find that the difference in earnings is value relevant in the transition year for firms providing more than the average disclosure about the impact of IFRS transition. Our results suggest beneficial effects for firms providing more detailed explanations of IFRS impact and confirm that transition disclosures have economic importance.

The evidence of our study are important because of the costs associated with the regulation of financial reporting and with firm disclosure. Our results on the relationship between firm incentives, mandatory accounting standards and firms' actual disclosures extend our understanding of how the financial reporting setting and firm incentives influence practice. Questions have been raised about the global application of IFRS and the effect of firm incentives and a country's institutional setting on the quality of reporting under IFRS (Christensen et al., 2008; ESMA, 2011; SEC 2011). Our study is relevant to this debate and provides insights that may be useful for parties promulgating and enforcing accounting standards. It also contributes to the evaluation of the benefits of IFRS in Australia. The findings are relevant to countries engaged in or considering adoption of IFRS as regulators determine the extent to which mandatory disclosure requirements are necessary and useful. 


\section{Background and research predictions}

\subsection{Incentives for disclosure}

There are many institutional factors that could affect firms' disclosures about the impact of IFRS for Australian firms. Mandatory standards (including AASB 1047 and AASB 101) promote disclosure about IFRS as firms seek to meet their compliance obligations. In addition, IFRS adoption was considered a major event in corporate Australia, promoting activity by preparers, auditors and market regulators (i.e., the ASX and ASIC) (Picker, 2006). The combined effect of mandatory standards and the scrutiny of auditors and regulators can be expected to promote compliance with accounting standards and disclosure requirements.

While disclosure about the impact of IFRS was mandatory, many aspects of firms' disclosure remain discretionary. That is, firms have some degree of control over content and attributes of disclosure (i.e., amount, spread and type) as well as its timing. In addition, firms have some choice in channel of disclosure, for example, via earnings forecasts, earnings announcements, statutory financial statements, investor presentations and press releases. Given that managerial incentives may affect firms' disclosure (Healy and Palepu, 2001) we expect variation between firms in the content and timing of their IFRS disclosures and the use of different channels for such disclosure. Holland $(1998 ; 2005)$ proposes that changes in financial data in firm accounts create a setting where firms have strong incentives (linked to the share price effects of information and consequently cost of capital) to provide information to prevent 'earnings surprises'. He argues that the magnitude of a change is important, not its direction. A change such as IFRS adoption creates uncertainty with regards to the impact on financial accounts and managers are likely to explain away this uncertainty.

However markets are generally more sensitive to 'bad news' compared to 'good news'. Firms are cautious when reporting earnings downgrades and losses because of the implications for analyst forecasts, future performance and consequent impact on share price (Graham et al. 2005). Studies have shown poor performance brings about more detailed explanations (Bloomfield 2008), longer conference calls to analysts (Matsumoto et al. 2011) and increase in the content of management discussion and 
analysis reports (Brown and Tucker 2010). Consistent with disclosure being important to external users, Barton and Mercer (2005) show the plausibility of firm explanations for poor performance affects judgements by analysts about future firm performance. Other studies report earlier disclosure of bad news, possibly to reduce litigation risk (Skinner 1994, 1997; Soffer et al. 2000; Kothari et al. 2009).

Thus we propose that firms' narrative disclosures about the impact of IFRS are linked to the adverse effect of IFRS adoption on the financial accounts (specifically, measures of earnings and book value of equity). Firms experiencing an adverse change have greater incentive to provide more explanation of the change, to ensure that capital market participants are fully informed about the reasons for the change so that their assessments of current position and performance and future prospects are accurate. IFRS effects may be observed in both earnings and equity (in the latter, through the flow of current earnings to retained earnings and directly through changes in measurement of assets and liabilities). We expect firms to focus on disclosure about adverse (i.e., downwards or negative) changes in earnings due to the primacy of reported earnings. We also expect more disclosure about adverse changes in book value of equity because equity values carry forward into the following year and form part of key performance ratios such as return on equity. However, an important aspect of our investigation is that the change in earnings at transition to IFRS is a book entry (i.e., a change from alteration to accounting recognition and measurement rules) not a change reflecting performance (i.e., a change in underlying firm economics).

Similarly, we propose earlier disclosure of IFRS effects for firms experiencing greater adverse IFRS financial impact. Early release of information will give market participants more time to absorb the information and avoid misunderstandings. This view is consistent with Grossman (1981) who argues that, to avoid the costs of adverse selection, all firms are expected to disclose information as quickly as possible. Diamond's (1985) proposition that firms adopt disclosure policies that result in private information search savings also fits with the argument that firms with the most to lose from non-disclosure (in our case, from investors misinterpreting the financial impact of IFRS) will make earlier disclosures, for example in their IFRS transition year rather than the adoption year. 


\subsection{Multiple disclosure media}

Prior studies of Australian firms' IFRS transition disclosure show disclosure varies with firm attributes and incentives. Using a sample of 150 firms, Palmer (2008) reports more transition disclosure by larger firms, those with more leverage and firms audited by a Big 4 auditor. Gallery et al. (2008) extends the work of Palmer by considering a larger sample of 408 firms and using a detailed disclosure checklist (with a score range of 1-17) that measures quality of disclosure in the transition reconciliation statement and the accompanying narrative disclosure. The authors find the quality of disclosure is negatively associated with IFRS impact on profit and positively associated with firm size and change in profitability. The authors report that disclosure quality varies between industries and clients of Big 4 audit firms. Kent and Stewart (2008) use sentence counts to measure disclosure for 965 firms. They argue that measures of the quantity of disclosure proxy for more detailed and thus more transparent disclosure. The authors conclude that IFRS transition disclosure is positively related to corporate governance indicators such as the number of board and audit committee meetings and choice of a Big 4 auditor.

Because statutory financial statements are not a timely medium for reporting information (Ball and Brown 1968), some firms will make disclosure through other media to ensure information is communicated effectively (Gibbins et al. 1990, Holland 1998; 2005). Continuing our arguments above, we expect that firms experiencing greater adverse IFRS impact to use more communication channels and provide more disclosure to achieve greater transparency about the effect of transition to IFRS. When discussing mandatory reporting practices, corporate preparers have indicated that the statutory disclosures are finalised, approved by the board and audited. Firm announcements and investor presentations are then prepared, based on material in the statutory accounts (Tarca et al. 2011). Therefore we expect disclosure in firm announcements to complement (rather than substitute for) disclosure in the financial statements. ${ }^{1}$

\footnotetext{
${ }^{1}$ The way security analysts use firms' releases also suggests a complementary relationship. Anecdotal evidence indicates that analysts initially extract information from earnings announcements and investor presentations, later supplementing this with material taken from the statutory financial statements, reflecting the timing of release of the documents.
} 


\subsection{Value relevance of IFRS transition disclosure}

Several studies consider the financial impact of the transition from national GAAP to IFRS and whether the use of IFRS improves value relevance of numbers in the statutory accounts. Prior to its adoption, some held the view that IFRS transition disclosure would provide no additional information so capital market effects would be negligible (Horton and Serafeim 2009). On the other hand, survey evidence (PricewaterhouseCoopers 2006; KPMG 2005) suggests that mandatory IFRS disclosure will have capital market effects because investors perceive an increase in the quality of management information, improvement in corporate transparency and enhanced comparability between jurisdictions and industry sectors.

Hung and Subramanyan (2007) find that on transition to international standards reconciliation information about changes in equity in German firms is value relevant while information about changes in earnings is not. In contrast, Horton and Serafeim (2009) report that changes in earnings on transition are value relevant for UK firms. Barth et al. (2011) who find differences in value relevance of transition reconciliations between three country groupings based on legal system (English, French/German and Scandinavian) as well as industry sector (financial and nonfinancial). Christensen et al. (2009) suggest that IFRS transition can have economic effects if the restated numbers have implications for breaching debt covenants. The authors find larger reactions to earnings reconciliations from UK GAAP to IFRS for firms with a greater likelihood of covenant violations.

Some evidence suggests that IFRS reconciliation disclosures do not contain new information in relation to Australian firms, possibly because of the relatively high level of harmonisation of Australian GAAP (AGAAP) and IFRS before adoption (Picker, 2006). Goodwin et al. (2008) study 1,065 Australian firms and report that IFRS earnings and book values are not more value relevant than AGAAP measures even though firms experienced, on average, a reduction in earnings when they transitioned from AGAAP to IFRS. Similarly, Becis et al. (2007) do not find a market reaction to the release of reconciliation information for large Australian firms. Clarkson et al. (2011) find no change in the value relevance of book value and earnings for prices before and after mandatory IFRS adoption in 2005 for firms in the 
European Union and Australia. However, considering a longer time period (19902008) Chalmers et al. (2011) find an improvement in value relevance of earnings, but not book value of equity following IFRS adoption, for their sample of mainly industrial firms.

It may be that managers do not consider the IFRS transition amounts to have information content and thus do not expend special effort explaining the change beyond that required to satisfy mandatory disclosure standards. Therefore we investigate the relevance of IFRS impact disclosure by considering first, whether firms' reported changes in earnings and equity on transition to IFRS are value relevant and, second, whether the narrative disclosure about IFRS impact (i.e., explanations of the impact of IFRS on earnings and equity at transition) contributes to higher value relevance.

\section{Design, sample and data}

\subsection{Sample selection}

The Australian setting is appropriate for this study for several reasons. The domestic capital market, although relatively small, is highly developed with sophisticated participants and information exchange mechanisms. External sources of finance are important and the quality of firms' disclosures and communication with outsiders attracts a great deal of attention, both within firms and in the public domain. In Australia, IFRS adoption was mandatory for all reporting entities for financial years commencing 1 January 2005 and early adoption was not permitted. Sample firms were selected from the S\&P ASX 200. Firms were required to be followed by at least three analysts (to include firms for which public disclosures are important) and to use AGAAP then IFRS. This reduced the sample to 150 and reflects the extent of analyst following of Australian firms.

Our sample is smaller than that used by Gallery et al. (2008) and Kent and Stewart (2008) but consistent with that of Palmer (2008), who argues that 150 firms are sufficient for robust statistical testing. In addition, our sample represents approximately $80 \%$ of the capitalisation of the Australian market, thus includes the most economically important firms. Three financial years are included: prior to IFRS adoption; when IFRS comparative data was prepared; and first year of full IFRS 
adoption (hereafter pre-transition, transition and adoption). ${ }^{2}$ Financial statements were obtained from the Connect 4 database and firm announcements from the Securities Industry Research Centre of Asia-Pacific (SIRCA).

\subsection{Measurement of IFRS disclosure}

We measured the extent of disclosures about the effect of IFRS adoption in firms' statutory annual financial statements during the three financial years and in firm announcements to the ASX during 2005 and $2006 .^{3}$ In the two years prior to adoption, AASB 1047 Disclosing the Impacts of Adopting Australian Equivalents to International Financial Reporting Standards required firms to explain (a) how the transition to IFRS was managed and (b) the key differences in accounting policies arising from IFRS adoption (paragraph 4.1). In the adoption year AASB 101 First Time Adoption of Australian Equivalents to IFRS applied. ${ }^{4}$ Firms were required to explain how the transition from previous GAAP to IFRS affected reported position, performance and cash flows (paragraph 38). In addition, firms were required to meet continuous disclosure obligations under Corporations Law and the need to report any material changes in financial performance or position from IFRS was emphasised (ASIC 2004).

Researchers commonly use word or sentence counts to measure disclosure (Beattie et al. 2004). However, measures of magnitude are limited in what they can reveal about the nature of the underlying disclosure. We follow the approach of Palmer (2008) and Gallery et al. (2008) by using a self-constructed checklist to measure financial

\footnotetext{
${ }^{2}$ The majority of firms have a 30 June year end (102 firms, 68\%) so the years in the study end 30 June 2004, 2005 and 2006. However, 27 firms (18\%) have a December year end and 21 (14\%) have another date for their financial year end. In these cases, years included vary to reflect financial year end dates. Earliest years are December 2003 - December 2005 and latest years are November 2004 November 2006.

${ }^{3}$ Due to the intensive and time consuming nature of data collection, we selected specific disclosure documents for our study. We chose annual statutory financial statements as they are arguably the most important information releases made by a firm. Due to resource constraints, we did not code disclosures in half-yearly statutory financial statements in 2004-2006 or firm announcements in 2004. We justify not including the interim reports for the following reasons. First, interim reports are not provided to shareholders and therefore are distributed less widely than annual reports. Second, interim reports are not audited and only reflect an interim position. Third, a review of interim reports of some of the sample companies suggested that interim reports were not greatly used to convey IFRS information.

${ }^{4}$ Equivalent to IAS 1. Australian accounting standards (AASB) are based word-for-word on IAS and IFRS issued by the International Accounting Standards Board (IASB) with additional paragraphs added by the Australian Accounting Standards Board in relation to requirements for not-for-profit and public sector entities.
} 
statement disclosure about IFRS effects. However, our checklist is more comprehensive than those used in the two prior studies. It has 11 categories, organised in three groups. They are: (A) Financial Performance \#1 Revenue, \#2 Expenses, \#3 - \#4 Profit; (B) Financial Position \#5 Assets, \#6 Liabilities, \#7 Equity, \#8 Total figures; and (C) IFRS comments \#9 Impact, \#10 Volatility, \#11 Other. Following Beattie et al. $(2002 ; 2004)$ we consider three attributes of disclosure. We measure amount of disclosure by recording all items relating to IFRS impact in the relevant documents, spread of disclosure by using the three groups A, B and C above and type of disclosure by recording whether a disclosure item was qualitative or quantitative.

Based on the financial statement checklist (Appendix 1), a firm received one point each time a checklist item was discussed, that is, scores greater than one are possible for each item and the checklist has no maximum score. A firm was awarded one point for a qualitative disclosure with an additional one point for providing quantitative disclosure as well. Qualitative disclosures related to descriptive statements of fact or statements based on matters of judgement that did not include numerical estimation. Quantitative disclosures on the other hand referred to narrative disclosures that were supported by factual statements and numerical measurements. Two coders, trained by the researchers, read all documents separately, recorded data to checklists, then compared their coding to each other's and reconciled any differences to improve reliability in the coding process (Behn et al. 2001).

For firm announcements, we collected all documents lodged with the ASX in 2005 and 2006. ${ }^{5}$ They were searched for mention of IFRS, then checked for usable content (e.g., IFRS discussion, not just the word IFRS). Disclosure in firm announcements was coded based on a simplified version of the checklist used to measure financial statement disclosure (Appendix 2). Since detailed information was already captured

\footnotetext{
${ }^{5}$ For example, for firms with a 31 December year end (the earliest Australian firms to adopt IFRS), announcements about full year results from transition year (i.e., FYE 31 December 2004) would appear from approximately February 2005. For firms with 30 June year ends, announcements about full year transition year results would appear from approximately August 2005. We expect most discussion of impact of adoption in the full year results announcements for the transition year, that is, when the financial impact is quantified and transition to IFRS balances are known. The applicable dates would begin February 2006 for 31 December year end firms and August 2006 for 30 June year end firms. We have not included 2004 as these announcements would mainly discuss results from the prior year 2003, which is outside our period of interest.
} 
in the financial statements, the aim when coding these firm announcements was to record any additional information provided.

In relation to the income statement, firms received one point for discussion of one element of the income statement and an additional point for discussion of one or more elements; one point if overall impact was discussed and another point if impact was quantified (consistent with Palmer (2008) who argues that quantification increases the quality of the disclosure); one point if impact for one or more segments was discussed and another point if an alternative income measure (i.e., a non-GAAP or proforma income measure) was discussed; one point if overall ratios were discussed and up to two more points if one or more individual ratios were discussed. One more point was given if ratios relating to segments were discussed. A similar approach was followed for coding discussion of balance sheet information. In addition, comments about IFRS were scored, with up to two points given for discussion relating to each of the following: overall impact, volatility; other IFRS comments; alternative measures; and the 'standard' IFRS comment. ${ }^{6}$

\subsection{Models}

The following models are used to investigate whether firms' IFRS disclosures are related to the impact of IFRS adoption on earnings and equity.

$$
\begin{aligned}
\text { Discls } & =\alpha_{0}+\alpha_{1} \Delta \text { Earn }_{T A}+\alpha_{2} \Delta \text { Equity }_{T A}+\alpha_{3} \Delta \text { Earn }_{T T}+\alpha_{4} \Delta \text { Equity }_{T T}+\alpha_{5} \text { Adopt } \\
& +\alpha_{6} \text { Transit }+\alpha_{7} \text { Size }+\alpha_{8} \text { Analysts }+\alpha_{9} \text { Leverage } \\
& +\alpha_{10} \text { Loss }+\alpha_{11} \text { Issues }+\alpha_{12} \text { Finance }+\alpha_{13} \text { Mining }+\alpha_{14} \text { ForList }+\varepsilon
\end{aligned}
$$

where

$$
\begin{aligned}
\text { Discls = } & \text { the measure of disclosure (including amount, spread and type) about } \\
& \text { the impact of IFRS adoption in either of two media (annual statutory } \\
& \text { financial statements and firm announcements); } \\
\Delta \operatorname{Earn}_{T A}= & \text { the change in IFRS earnings in adoption year scaled by total assets at } \\
& \text { year end; }
\end{aligned}
$$

\footnotetext{
${ }^{6}$ The 'standard' IFRS comment was a statement commonly included, stating that while IFRS adoption changed financial measures it did not change the firm's underlying economics.
} 


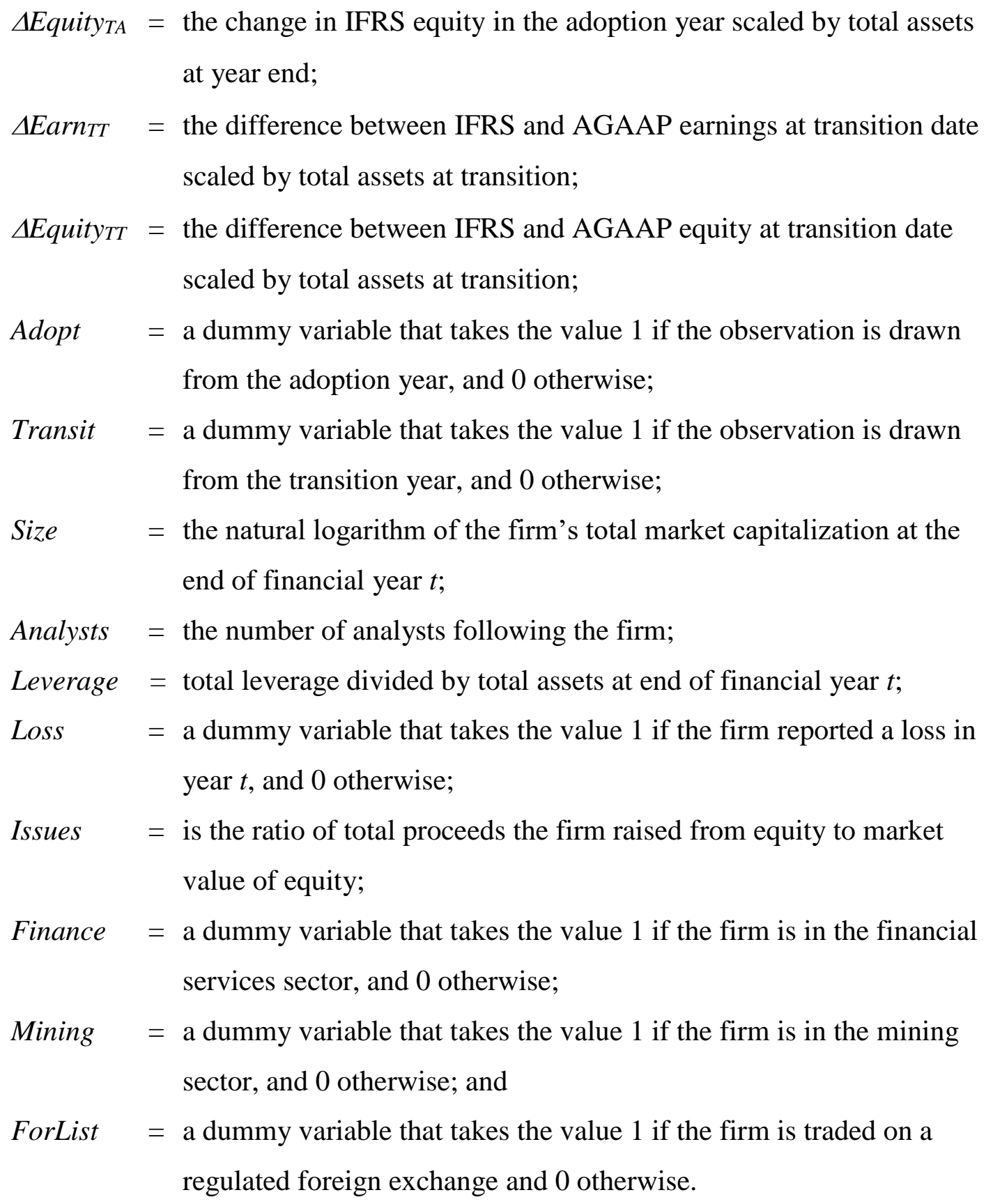

The regression model, based on Brown et al. (1999), is estimated using pooled data and fitted with various measures of disclosure as the dependent variable. The measures of disclosure include total disclosure, disclosure about financial position, financial performance, quantitative and qualitative disclosure, and disclosure about key items expected to be most affected by IFRS and IFRS comments disclosure. We include robust standard errors to correct for heteroscedasticity in the residuals. 
We measure the financial impact of adoption of IFRS using the following variables. $\triangle E a r n_{T A}$ and $\triangle E q u i t y_{T A}$ measure the change in earnings and book value of equity in the adoption year and $\Delta E a r n s_{T T}$ and $\Delta E q u i t y_{T T}$ measure the change arising on transition from AGAAP to IFRS. Specifically, $\Delta E_{a r n}{ }_{T A}\left(\Delta E q u i t y_{T A}\right)$ is the change in IFRS earnings (book value of equity) in the adoption year, divided by total assets at year end to control for size differences between firms (Equation 2). $\Delta E_{a r n} n_{T T}$ $\left(\triangle E E_{\text {quity }}\right.$ TT) is the difference between IFRS earnings (book value of equity) and AGAAP earnings (book value of equity) at the date of transition, scaled by total assets at year end (Equation 3). Our variable definition is consistent with Gallery et al. (2008) and similar to other studies using transition adjustments (Hung and Subramanyan 2007; Clarkson et al. 2011; Barth et al. 2011) where various deflators have been used. ${ }^{7}$

$$
\begin{aligned}
& \Delta \operatorname{Earn}_{T A}=\frac{\left(\text { Earn }_{I F R S_{-} \text {Adoption }}-\text { Earn }_{\text {IFRS_Transition }}\right)}{\text { Total_assets }_{\text {Adoption }}} \\
& \Delta \operatorname{Earn}_{T T}=\frac{\left(\text { Earn }_{\text {IFRS_Transition }}-\text { Earn }_{\text {AGAAP_Transition }}\right)}{\text { Total_assets }}
\end{aligned}
$$

A positive value for $\triangle \operatorname{Earns}_{T A}$ means IFRS earnings increased in the adoption year while a positive value for $\triangle E_{\text {arns }}$ TT means IFRS earnings is greater than AGAAP earnings at transition. Consistent with Gallery et al. (2008), we predict a negative relationship between changes in earnings and equity at transition with IFRS disclosure. That is, firms experiencing a greater adverse change in earnings and equity on transition to IFRS are more likely to provide more disclosure. ${ }^{8}$

We include the year dummy variables (Adopt, Transit) to detect changes in disclosure across the years (consistent with Brown et al. 1999). We predict positive coefficients for the dummy variables as we expect disclosure to increase over the

\footnotetext{
${ }^{7}$ Horton and Serafeim (2009) calculate the difference between GAAP and IFRS earnings and equity at transition and deflate the earnings change by GAAP earnings and the equity change by book value of equity. In robustness tests, we re-run all our models with $\triangle E a r n_{T T}$ and $\Delta E q u i t y_{T T}$ deflated by book value of equity instead of total assets. The results for these models are qualitatively similar to those reported elsewhere in our study.

${ }^{8}$ The directional relationship of the IFRS impact variables and the disclosure variables reflects the way IFRS impact is defined. Thus a negative coefficient indicates that, as positive numbers become smaller and negative numbers become larger, firms are more likely to provide greater disclosure.
} 
period as firms become more certain of IFRS effects. There is an extensive disclosure literature that reports more disclosure by larger firms and those followed by more analysts (see for example, Craswell and Taylor 1992; Hossain and Adams 1995; Lang and Lundholm 1996; Brown et al. 1999). In addition, firms raising capital and with foreign exchange listings provide more disclosure (Hossain and Adams 1995; Meek, Roberts and Gray 1995). Leverage may also be associated with disclosure (Christensen et al. 2009). Thus we include control variables for size (Size), number of analysts following the firm (Analysts), leverage (Leverage), capital raising (Issues) and foreign listing (ForList). ${ }^{9}$ Because Gallery et al. (2008) suggest firms experiencing unexpected changes in earnings and losses provide more disclosure, we include a loss dummy variable (Loss). In our models changes in earnings is captured in the $\Delta E a r n_{T A}$ variable.

Two industry dummy variables are included (Finance, Mining) because IFRS adoption (particularly IAS 39) may affect the results of firms in the financial sector and mining sector more than other firms (Goodwin et al. 2008; Barth et al. 2011). ${ }^{10}$ Prior studies investigating transition disclosure and industry effects report mixed results. Kent and Stewart (2008) find an association between disclosure and being a firm in the finance or mining sector while Gallery et al. (2008) and Palmer (2008) find no such association. ${ }^{11}$

Finally, to explore the relevance of disclosure about IFRS impact, we use the price level model adopted in prior studies (Barth and Clinch 1998; Goodwin et al. 2008; Chalmers et al. 2011), derived from Ohlson (1995).

Price $=\alpha_{0}+\alpha_{1} B V E+\alpha_{2} N I+\alpha_{3} \Delta E a r n_{T T}^{\prime}+\alpha_{4} \Delta E q u i t y_{T T}^{\prime}+\varepsilon$

\footnotetext{
${ }^{9} \mathrm{We}$ have not included corporate governance variables as corporate governance is a complex concept not easily proxied by individual corporate governance variables (such as having a non-executive chair, proportion of independent directors or the number of meetings). To extend the work of Kent and Stewart (2008) would require identifying better proxies for corporate governance, which we considered beyond the scope of our paper.

${ }^{10}$ Type of auditor is an important explanatory variable for disclosure in Gallery et al. (2008), Kent and Stewart (2008) and Palmer (2008). However, we do not include a variable representing type of audit firm as only six of the sample companies are not audited by a Big 4 firm.

${ }^{11}$ In Palmer's (2008) study, mining firms are included in the materials sector.
} 
where

$$
\begin{aligned}
\text { Price }= & \text { a firm's share price three months after end of year } t ; \\
B V E & \text { book value of equity per share, at year end } t ; \\
N I & \text { earnings per share, for year } t ; \\
\Delta E a r n_{T T}^{\prime}= & \text { the difference between IFRS and AGAAP earnings at transition date, } \\
& \text { divided by number of shares; } \\
\Delta E q u i t y_{T T}^{\prime}= & \text { the difference between IFRS and AGAAP equity at transition date, } \\
& \text { divided by number of shares. }
\end{aligned}
$$

The model tests the value relevance of accounting data by exploring the relationship of price, book value of equity and earnings (deflated by number of shares to control for scale effects). ${ }^{12}$ Based on prior research, we predict book value of equity and earnings to be relevant to share price, and expect positive coefficients on $B V E$ and NI. Consistent with Hung and Subramanyan (2007), Goodwin et al. (2008) and Barth et al. (2011), we add variables to measure the financial effect of adoption of IFRS (the difference between measures of earnings and equity under AGAAP and IFRS, in our case $\Delta E a r n_{T T}^{\prime}$ and $\left.\Delta E q u i t y_{T T}^{\prime}\right)$. Significant positive coefficients on $\Delta E a r n_{T T}^{\prime}$, and $\Delta$ Equity $_{T T}^{\prime}$ suggest that the amount of the change from AGAAP to IFRS is value relevant.

We also consider the relevance of transition disclosure by identifying 'high disclosing' firms, using two approaches. In our primary tests, we identify high disclosing firms using the fitted models (Equation 1) of disclosure in (a) the financial statements and (b) firm announcements respectively. For each of the two models, we create two groups based on whether the firm-year observation has a positive or negative residual. Firm-year observations with positive residuals are identified as having higher than expected disclosures and those with negative residuals are identified as having lower than expected disclosures. Positive coefficients for $\Delta$ Earn $_{T T}^{\prime}$, or $\Delta E_{\text {quity }}^{\prime}$ in models for the high disclosing group shows that IFRS impact disclosure has assisted market participants to interpret the transition

\footnotetext{
${ }^{12}$ In Equation (4) all variables are scaled by number of shares, to control for heteroscedasticity in the levels model (Goodwin et al. 2008). In Equation (1) $\Delta E_{a r n}{ }_{T T}$ and $\Delta E q u i t y_{T T}$ are scaled by total assets to control for differences in size between firms.
} 
reconciliation amounts. In robustness tests, instead of the residuals we use firms' scores for total disclosure (Discls) in (a) the financial statements and (b) firm announcements to form the subgroups.

\section{Results}

\subsection{Summary statistics}

Table 1 (Panel A) shows a seven-fold increase in total amount of IFRS impact disclosure $\left(\right.$ Total $\left._{F S}\right)$ over the three years, from an average total score of 14 in the pretransition year to 100 in the adoption year. In all years, firms on average provide more disclosure about financial position $\left(\right.$ Position $_{F S}$ ), suggesting that explaining asset, liability and equity effects is relatively more important to firms. In the adoption year mean Position $F S$ score is 74 while the mean total disclosure (Total $F S$ ) score is 100 (Panel C).

Firms on average provide more qualitative disclosures in all three years examined, with differences in the amount of qualitative and quantitative disclosures narrowing over the period. In the pre-transition year, mean qualitative disclosure is 14 (compared to mean Total $F S$ of 14) and in the adoption year it is 57 (compared to mean Total $_{F S}$ of 100). The proportions are not surprising because firms are required to state their financial performance and position figures under IFRS for financial years beginning 1 January 2005 while they were only required to discuss the impact of the IFRS in the prior years. Also, firms could be more specific as more information was revealed with the passage of time. Mean disclosure about key items

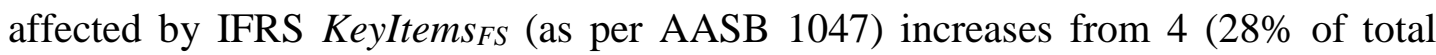
disclosure) in pre-transition to $20(20 \%)$ in adoption year. The proportions suggest that a large amount of discussion is not about key items, raising questions about its relevance.

\section{[Insert Table 1 about here]}

In relation to disclosure scores in firm announcements about IFRS effects, there were 338 announcements in 2005 and 328 in 2006. On average, firms provided two public announcements in both the transition and adoption years however one firm provided 
19 announcements in the transition year and another 17 in the adoption year (Table 2). The average timing of announcements ( $\mathrm{Lag}$ ) was 71 days after year end in the transition year and 84 days in the adoption year. The minimum time to release was 23 days and the maximum 238 days in the adoption year compared to 25 days and 162 days in the transition year. Considering the mean and maximum number of days, firms made their announcements earlier in the transition year.

For most firms, discussion of IFRS impact was included in the firm's half-year results announcement or the preliminary financial statements issued after financial year end. Untabulated data show that of the 666 announcements we coded in 2005$2006,21 \%$ were announcements made on or near the release of the half-yearly results and $55 \%$ were made on or near the release of the full year preliminary financial statements (within a three day window). Only 29 announcements were stand-alone IFRS statements. They were released by 22 large firms, of which 10 were from the financial services sector. Of the 29 , only 12 announcements were released on a day other than when the half-year or yearly results were released. On average, these 12 documents were lodged 35 days after the nearest financial period end. Thus, we conclude that firms were most likely to discuss the effects of IFRS adoption within their period-end disclosures. Separate documents and documents released prior to end of the financial period were rare.

Table 2 shows the mean Total $_{C A}$ disclosure is higher in transition year compared to adoption (11 compared to 7). Similar to financial statement disclosure, the proportion of qualitative disclosure is lower in the adoption year (7 qualitative versus 2 quantitative in the transition year; 3 qualitative versus 2 quantitative in the adoption year). Mean scores for Perform ${ }_{C A}$ and Position $C A$ are similar within and between years. However, the range of scores is high, with Total $_{C A}$ disclosure scores reaching a maximum of 81 in the transition year and 94 in the adoption year. In the subcategories of disclosure, one firm recorded the maximum score of 43 for IFRS comments (Comments CA $_{\text {) }}$ in transition year and another recorded the maximum score of 47 for Perform $C A$ disclosure in adoption year.

[Insert Table 2 about here] 
The summary statistics for the independent variables are provided in Table $3 .^{13}$ The sample includes the largest Australian firms, with average market capitalization of AUD 2.0 billion at the transition year end. Firms vary in size from AUD 120.8 million to AUD 109.9 billion (Std. dev $=13.18$ billion) indicating the sample includes a range of firms based on size. They are, on average, covered by seven analysts. Mean leverage is $53 \%$ and, on average, capital raising represents $4.9 \%$ of market value of equity in the period. The sample included 93 firm-years $(20.7 \%)$ from the financial services sector and 45 firm-years (10\%) from the mining sector. Forty-five firms are cross-listed or traded on a foreign stock exchange and 26 firmyears $(5.8 \%)$ incurred a loss in the study period.

For the transition year (AGAAP to IFRS), firms, on average, restated their equity at a lower value $\left(\Delta E\right.$ Eqity $\left.{ }_{T T}=-0.032\right)$ and their earnings at a higher value $\left(\Delta \operatorname{Earn}_{T T}=\right.$ 0.004). In the adoption year, based on opening and closing IFRS balances, firms experienced a mean increase in equity $\left(\Delta E q u i t y_{T A}=0.078\right)$ and earnings $\left(\Delta\right.$ Earn $_{T A}=$ $0.012)$

[Insert Table 3 about here]

Table 4 shows significant correlations between the various measures of disclosure. Not surprisingly, measures of financial statement disclosure about IFRS impact on position and performance (Perform ${ }_{F S}$, Position $F S$ ) are positively correlated with total disclosure $\left(\right.$ Total $\left._{F S}\right)(0.79 ; 0.99)$ and with each other $(0.71)$. Similarly, IFRS impact disclosure in firm announcements about position and performance (Perform ${ }_{C A}$, Position $\left._{C A}\right)$ are positively correlated with total disclosure $\left(\right.$ Total $\left._{C A}\right)(0.93 ; 0.92)$ and with each other (0.78). Scores for financial statement disclosure and firm announcement disclosure are significantly positively correlated (0.34) but the level is relatively low.

The total disclosure scores from financial statements (firm announcements) are significantly and positively correlated with firm size at $0.42(0.50)$, analyst following $0.20(0.38)$ and leverage $0.43(0.34)$. Thus larger firms and those with more analyst

\footnotetext{
${ }^{13}$ The independent variables were examined for outliers and extreme values are winsorised at three standard deviations.
} 
following provide greater disclosure and the relationship is stronger for disclosure in firm announcements. Disclosure scores (in total and for position and performance) are generally not significantly correlated with the change in earnings and equity variables, suggesting a lack of association between amount of disclosure and IFRS impact. Significant negative correlations are observed between Total $_{F S}$, Perform $F S$, Position $_{F S}$ and $\Delta$ Earn $_{T A}\left(-0.13,-0.13\right.$ and -0.12) and $\Delta$ Equity $_{T A}(-0.14,-0.10$ and 0.14). A negative correlation suggests more disclosure by firms with smaller changes in earnings and equity. No significant correlations are observed between the variables capturing firm announcement disclosure (i.e., Total ${ }_{C A}$, Perform $_{C A}$ and Position PA) $_{\text {) }}$ and the variables measuring IFRS impact (i.e., $\Delta E_{a r n}, \Delta E q u i t y_{T T}, \Delta E a r n_{T A}$ and $\Delta$ Equity $\left._{T A}\right)$.

[Insert Table 4 about here]

\subsection{Regression results}

Table 5 presents the pooled model and models for 'good news' $\left(\Delta \operatorname{Earn}_{T A}>0\right)$ and 'bad news' $\left(\Delta \operatorname{Earn}_{T A}<0\right)$ firms in Panel A. The transition and adoption year models are presented in Panel B. The models include financial statement disclosure about IFRS impact $\left(\right.$ Total $\left._{F S}\right)$ as the dependent variable, four measures of the IFRS financial impact ( $\triangle E_{\text {Equity }}$, $\Delta E_{\text {Earn }} T A, \Delta E q u i t y_{T T}$ and $\left.\Delta E a r n_{T T}\right)$ and control variables. Table 6 presents the same models but with total disclosure in firm announcements (Total ${ }_{C A}$ ) as the dependent variable. ${ }^{14}$

\subsubsection{IFRS financial impact and disclosure}

In the pooled model (Table 5, Panel A) coefficients on $\Delta E a r n_{T T}$ and $\Delta E a r n_{T A}$ are negative and significant $(-2.174, \mathrm{p}<0.05$ and $-0.820, \mathrm{p}<0.05)$, suggesting disclosure is higher for firms with a smaller change. That is, firms with more adverse (less positive) financial impact are likely to provide more disclosure compared to firms with less adverse (more positive) financial impact. We observe a similar pattern for disclosure in the firm announcements. In the pooled model (Table 6, Panel A) coefficients on $\Delta \operatorname{Earn}_{T T}$ and $\Delta \operatorname{Earn}_{T A}$ are negative and significant $(-0.305, \mathrm{p}<0.10$ and $-0.214, \mathrm{p}<0.01)$.

\footnotetext{
${ }^{14}$ All dependent variables are scaled by dividing by 100 to reduce the size of the coefficients on the independent variables.
} 
[Insert Tables 5 and 6 about here]

In addition, we find the relationship of IFRS impact and disclosure is observed in the adoption year for financial statements and the transition year for firm announcements. Coefficients on $\triangle E a r n_{T T}$ and $\triangle E a r n_{T A}$ are negative and significant in the adoption year $(-6.364, \mathrm{p}<0.01 ;-2.334, \mathrm{p}<0.01)$ for financial statement disclosure (Table 5, Panel B). Table 6 (Panel B) shows that the relationship between disclosure in firm announcements and IFRS financial impact occurs earlier, and in both the transition and adoption years. Coefficients on $\Delta E E_{\text {quity }}{ }_{T T}$ and $\Delta E a r n_{T A}$ are negative and significant $(-0.198, \mathrm{p}<0.05$ and $-0.340, \mathrm{p}<0.01)$ in the transition year model and $\triangle$ Equity $_{T A}$ is negative and significant $(-0.073, \mathrm{p}<0.05)$ in the adoption year. This result suggests that firm announcements are used to provide earlier communication of IFRS information.

\subsubsection{Disclosure by 'bad news' firms}

To investigate the effect for firms experiencing a positive change (earnings increases) compared with those experiencing a negative change (earnings decreases), we split the sample based on positive (good news) or negative (bad news) values for $\Delta$ Earn $_{T A}{ }^{15}$ Table 5 (Panel A) shows a negative coefficient on $\Delta \operatorname{Earn}_{T T}(-5.444$, $\mathrm{p}<0.01)$ for bad news firms, thus supporting the prediction that firms with more adverse (less positive) impact on earnings provide more disclosure. The prediction is not supported in relation to changes in equity in the transition year: $\Delta E q u i t y T T$ is negative but not significant. This result is consistent with a focus on discussion of earnings effects of IFRS. However, $\Delta$ Equity $_{T A}$ is negative and significant $(-0.409$, $\mathrm{p}<0.05)$ indicating more disclosure about IFRS equity effects when equity declines in the adoption year, consistent with the transition IFRS earnings effects carrying forward to equity in the following year and requiring explanation.

This pattern is not observed for good news firms. The coefficients on the earnings and equity variables at transition are not significant. However, $\triangle \operatorname{Earn}_{T A}$ is negative

\footnotetext{
${ }^{15}$ We subdivide the sample into good and bad news firms, rather than include dummy variables for good news and bad news firms in the full sample model because the subsample approach allows variation in all variables included in the models, which permits us to better explore the relationship of the experimental and control variables with disclosure.
} 
and significant $(-1.144, \mathrm{p}<0.10)$, indicating more disclosure by firms with a relatively smaller increase in earnings in the adoption year. That is, for good news firms, disclosure is decreasing with earnings impact. Firms with smaller increases in earnings in the adoption year are more likely to discuss IFRS effects on earnings than firms with larger increases in earnings. A possible interpretation of this result is that firms with less good news arising from economic events (i.e., earnings increases due to business performance) make more use of IFRS disclosure to explain their results. This interpretation is consistent with what we observed for bad news firms, that is, when earnings are negative or increases in earnings are relatively smaller, firms are more likely to discuss IFRS effects. Stated another way, when economic performance is stronger, the firm provides less discussion of the accounting effects of IFRS.

In the models reported in Table 5, the coefficient signs on the control variables are as expected. In the pooled model, the year dummies (Transit, Adopt) are positive and significant, indicating that firms make more disclosure in both the transition and adoption years, compared to the pre-transition year. We include additional variables in our models to control for other factors that may influence the relationship between disclosure and the financial impact of IFRS. We observe positive and significant coefficients on variables for size, analyst following, leverage and being a financial sector firm. These variables have been reported by Palmer (2008), Gallery et al. (2008) and Kent and Stewart (2008) to be associated with higher levels of disclosure.

\subsubsection{IFRS disclosure channels}

The third prediction was that IFRS impact disclosures in firm announcements would complement the disclosure in the financial statements and that firms would use both the firm announcements and the financial statement disclosures to inform investors. In the pooled model (Table 6, Panel A), the coefficients on $\Delta E a r n_{T T}$ and $\Delta E a r n_{T A}$ are negative and significant $(-0.305, \mathrm{p}<0.10$ and $-0.214, \mathrm{p}<0.01)$ consistent with the results for financial statement disclosure (Model 5). However, when we consider the 'good news' and 'bad news' firms separately, we do not find a significant relationship between disclosure and the financial impact variables for 'bad news' firms. Although we show above that the firms adversely affected by IFRS (i.e., 'bad news' firms) provide more disclosure in the financial statements, we do not find 
these firms making greater use of the available additional communication channel provided via firm announcements.

The significant variables observed in the pooled model (Table 6, Panel A) are associated with the 'good news' firms. Coefficients on $\triangle E a r n_{T T}$ and $\Delta E a r n_{T A}$ are negative and significant $(-1.033, \mathrm{p}<0.05$ and $-0.680, \mathrm{p}<0.01)$, showing that disclosure is decreasing in earnings impact. As shown above for financial statement disclosure, disclosure in firm announcements is decreasing with earnings impact for 'good news' firms. That is, firms with smaller increases in earnings in the adoption year are more likely to discuss IFRS effects on earnings than firms with larger increases in earnings.

Looking more generally about the use of firm announcements, we observe that larger firms, firms with higher leverage and those from the financial services sector have higher levels of IFRS impact disclosure (Table 6). This applies to both 'good' and 'bad news' firms. In addition, firms in the latter group that issue equity or belong to the mining sector are more likely to provide greater disclosure.

\subsubsection{Robustness tests}

In robustness tests (untabulated), we explored whether the models for total disclosure in financial statements (Model 5) and in firm announcements (Table 6) were sensitive to the measure of disclosure used. Using the checklist data, we calculated measures based on subcategories of disclosure relating to impact on performance and on position. We also measured quantitative disclosure and qualitative disclosure and disclosure about the key financial statement items likely to be affected by IFRS. All the models for financial statement disclosure yielded results consistent with those reported for the pooled model with total disclosure as the dependent variable (Table 5, Panel A). That is, the coefficients on $\Delta E_{a r n} T$ and $\Delta \operatorname{Earn}_{T A}$ are negative and significant in all pooled models, irrespective of the measure of disclosure used, indicating that, overall, disclosure is decreasing with IFRS impact on earnings. Control variables were significant in the same pattern as reported in the pooled models in Table 5. 
The results for robustness tests for models using disclosure in firm announcements also provided results consistent with those for the pooled total disclosure model (Table 6, Panel A). The coefficients on $\triangle E_{a r n}$ TA were negative and significant in all pooled models, irrespective of the measure of disclosure. The coefficients for $\Delta \operatorname{Earn}_{T T}$ were negative and significant in the qualitative and quantitative disclosure models, but not in the position and performance models. As for financial statement disclosure, our results confirm that disclosure is decreasing with IFRS impact on earnings. Control variables were similarly significant to those reported in the pooled models in Table 5.

\subsubsection{Value relevance - IFRS disclosure}

Table 7 reports the results of models investigating the value relevance of the financial impact on earnings and equity at transition from AGAAP to IFRS and whether the value relevance of these transition amounts is affected by the accompanying narrative disclosure about the impact of IFRS adoption. As discussed above, prior evidence is mixed as to whether reconciliation amounts themselves are value relevant, depending on firm attributes (such as their country of origin, size and industry sector) and the individual reconciliation items investigated.

[Insert Table 7 about here]

Goodwin et al. (2008) report that changes in earnings and equity on transition are not value relevant for Australian firms. Consistent with these authors, we do not observe significant coefficients on $\Delta E_{\text {quity }}^{\prime}$ in any of the years in the study period or on $\Delta E a r n_{T T}^{\prime}$ in the pre-transition years. However, in contrast to Goodwin et al. (2008), the coefficient on $\Delta E a r n_{T T}^{\prime}$ is positive and significant in the transition year (5.015, $\mathrm{p}<0.10$, Table 7, Column A).

Next we consider whether transition reconciliation amounts ( $\Delta E_{\text {Euity }}^{\prime}$ and $\Delta E a r n_{T T}^{\prime}$ ) are more value-relevant for firms providing relatively more discussion of the transition amounts (i.e., more explanations about the financial impact of the transition to IFRS). As explained previously, the two subgroups are based on whether 
a firm-year's residual in Equation 1 is positive or negative. Firms in the positive residual group provide relatively more disclosure than firms in the negative residual group. Table 7 shows that the coefficient on $\Delta E_{a r n_{T T}^{\prime}}$ is positive and significant (8.89, $\mathrm{p}<0.05$, Column B) in the transition year only for firms that provide more financial statement disclosure about the financial impact of adoption. $\Delta \operatorname{Earn}_{T T}^{\prime}$ is positive but not significant for the negative residuals group (Column C).

A similar result is observed for firm announcements. The coefficient on $\Delta E a r n_{T T}^{\prime}$ is positive and significant $(6.78, \mathrm{p}<0.05$, Panel D) in the transition year for firms providing more disclosure about the financial impact of adoption in announcements. Once again, $\Delta E a r n_{T T}^{\prime}$ is positive but not significant for the negative residuals group (Column E). $\Delta$ Equity $_{T T}^{\prime}$ is not significant for either group.

In robustness tests (untabulated) we form groups based on firms' total disclosure score in (a) the financial statements and (b) firm announcements. We re-run the models reported in Table 7, Columns B-E. Results are qualitatively similar to those in Table 7 where $\Delta E a r n_{T T}^{\prime}$ is positive and significant for the positive residuals group only. Based on the findings above, we conclude that firms' narrative disclosures explaining the financial impact of adoption of IFRS transition were useful to market participants.

\section{Conclusions}

We investigated the content, timing and relevance of Australian firms' disclosure in annual statutory financial statements and firm announcements to the stock exchange about the impact of IFRS during a three year period surrounding adoption. Studies of adoption of IFRS suggest that effects of the new standards vary between countries and firms, reflecting both the regulatory setting in which financial reporting takes places (particularly the extent of difference between national GAAP and IFRS and the level of enforcement) and firm incentives that underlie their reporting choices and communication decisions. The period of adoption of IFRS provided a setting where we could explore how firms in a developed capital market with investor oriented financial reporting communicated information about IFRS financial changes, given 
that the IFRS effects are largely accounting changes and not changes in underlying economic fundamentals.

Overall, the results show firms are sensitive to the need to ensure reported financial changes are understood by market participants, irrespective of the source of the changes (i.e., an accounting change compared to an economic change). Some firms used both financial statements and firm announcements to promote understanding of the impact of IFRS on reported position and performance. In addition, they made use of the relatively greater freedom of firm announcements (which are unaudited and do not follow a legally specified format) to provide additional and earlier information.

Our findings suggest that communication about changes to reported earnings was a priority, consistent with earnings being the metric of primary interest in capital markets. In some ways this focus is surprising, as earnings changes on transition are accounting changes (i.e., book entries only) and it is the IFRS impact on equity that carries forward to future years and affects ratio calculations. We observe more disclosure by firms experiencing an adverse change in earnings, consistent with firms being more sensitive about possible misinterpretations of negative signals about future earnings. We find more disclosure of IFRS accounting effects when economic performance is weaker, consistent with poorer performing firms seeking to justify their performance.

The results suggest that disclosure in financial statements and firm announcements are complementary, with the latter providing additional information to supplement disclosure in the financial statements. The timing of disclosure suggests that firms may be less constrained in discussions in ASX announcements compared with the statutory accounts. We generally examine the two channels separately and do not explore the interrelationship between the two. However, this issue is worthy of further investigation in future research. ${ }^{16}$

Finally, we conclude that narrative transition disclosures were not just a 'box ticking' exercise. Narrative disclosures in both financial statements and firm announcements

\footnotetext{
${ }^{16}$ We thank the anonymous reviewer for the suggestion for further research.
} 
were useful to market participants in understanding the impact of the financial effect on transition. Thus, understanding the accounting impact of IFRS was likely to be important for predicting future earnings. The impact of IFRS on the analysis of company fundamentals is beyond the scope of this study but could be usefully investigated in subsequent research.

A limitation of our study is the relatively small sample size, reflecting the size of the Australian capital market. Due to the intensive nature of data collection, we include only annual statutory financial statements and one source of public announcements (those made to the stock exchange). While these are arguably the most important disclosure media, there may be other disclosures made in the period not captured in our study. Given our design, the results may not be generalizable to smaller firms or to other jurisdictions. Our findings are based on manual coding of disclosure. Despite controls over the coding process, measuring disclosure is a subjective process and thus may be measured with error. Nevertheless, our study contributes to an understanding of the impact of mandatory disclosure requirements and managerial incentives on firms' disclosure practices. 


\section{References}

Accountnet 2004, eGAAP update: Disclosing the impact of adopting AASB equivalents to IASB standards. Available at: http://www.gaap.com.au.

Ball R and Brown P (1968) An empirical evaluation of accounting income numbers. Journal of Accounting Research 6(2): 159-178.

Barth M and Clinch G (1998) Revalued financial, tangible, and intangible assets: Associations with share prices and non-market-based value estimates. Journal of Accounting Research 36(Supp): 199-233.

Barth M, Landsman W, Young D and Zhuang Z (2011) Relevance of differences between net income based on IFRS and domestic standards for European firms. SSRN eLibrary.

Barton J and Mercer M (2005) To blame or not to blame: Analysts' reactions to external explanations for poor financial performance. Journal of Accounting and Economics 39(3): 509-533.

Beattie V, McInnes B and Fearnley S (2004) A methodology for analysing and evaluating narrative in annual reports: A comprehensive descriptive profiles and metrics for disclosure quality attributes. Accounting Forum 28(3): 205-236.

Becis T, Ng C and Roca E (2007) Has the adoption of Australian International Financial Reporting Standards been value relevant? Conference presentation AFAANZ Gold Coast Australia July.

Behn B, Kaplan S and Krumweide K (2001) Further evidence on the auditor's goingconcern report: The influence of management plans. Auditing: A Journal of Theory of Practice and Theory 20(1):13-28.

Bloomfield R (2008) Discussion of "Annual report readability current earnings and earnings persistence". Journal of Accounting and Economics 45(2-3): 248-252.

Brown P, Taylor S and Walter T (1999) The impact of statutory sanctions on the level and information content of voluntary corporate disclosure. Abacus 35(2): 138-162.

Brown SV and Tucker JW (2010) Large-sample evidence on firms' year-over-year MD\&A modifications. Available at: http://ssrn.com/abstract=1452977

Chalmers K, Clinch G and Godfrey J (2011) Changes in value relevance of financial information upon IFRS adoption: Evidence from Australia. Australian Journal of Management 36(2): 151-173.

Christensen H, Lee E and Walker M (2008) Incentives or standards: what determines accounting quality changes around IFRS adoption. Working paper SSRN 1013054.

Christensen H, Lee E and Walker M (2009) Do IFRS reconciliations convey information? The effect of debt contracting. Journal of Accounting Research 47(5): 1167-1199.

Clarkson P, Hanna J, Richardson G and Thompson R (2011) The impact of IFRS adoption on the value relevance of book value and earnings. Journal of Contemporary Accounting and Economics 7(1): 1-19.

Craswell A and Taylor S (1992) Discretionary disclosure of reserves by oil and gas companies: an economic analysis. Journal of Business Finance and Accounting 19(2): 295-308.

Diamond D (1985) Optimal release of information by firms. Journal of Finance 40(4): 1071-1071.

Ernst and Young (2003) Accounting Brief: First time adoption of International Financial Reporting Standards. Ernst and Young Australia. 
European Securities and Markets Authority (ESMA) (2011) Activity Report on IFRS Enforcement in 2010. Available at: http://www.esma.europa.eu/system/files/2011 355.pdf.

Gallery G, Cooper E and Sweeting J (2008) Corporate disclosure quality: Lessons from Australian companies on the impact of adopting International Financial Reporting Standards. Australian Accounting Review 18(3): 257-273.

Gibbins M, Richardson A and Waterhouse J (1990) The management of corporate financial disclosure: Opportunism, ritualism, policies, and processes. Journal of Accounting Research 28(1): 121-143.

Graham J, Harvey C and Rajgopal S (2005) The economic implications of corporate financial reporting. Journal of Accounting and Economics 40(1-3): 3-73.

Grossman S (1981). The informational role of warranties and private disclosure about product quality. Journal of Law and Economics, 24(3): 461-483.

Goodwin J, Ahmed K and Heaney R (2008) The effects of International Financial Reporting Standards on the accounts and accounting quality of Australian firms: A retrospective study. Journal of Contemporary Accounting and Economics 4(2): 89-112.

Healy P and Palepu K (2001) Information asymmetry corporate disclosure and the capital markets: A review of the empirical disclosure literature. Journal of Accounting and Economics 31(1-3): 405-440

Holland J (1998) Private disclosure and financial reporting. Accounting and Business Research 28(4): 255-269.

Holland J (2005) A grounded theory of corporate disclosure. Accounting and Business Research 35(3): 249-267.

Horton J and Serafeim G (2009) Market reaction to and valuation of IFRS reconciliation adjustments: First evidence from the UK. Review of Accounting Studies 15(4): 725-751.

Hossain M and Adams M (1995) Voluntary financial disclosure by Australian listed companies. Australian Accounting Review 5(2): 45-55.

Hung M and K Subramanyam K (2007) Financial statement effects of adopting International Accounting Standards: the case of Germany. Review of Accounting Studies 12(4): 623-657.

Kent P and Stewart J (2008) Corporate governance and disclosures on the transition to International Financial Reporting Standards. Accounting and Finance 48(4): 649-671.

Kothari S, Shu S and Wysocki P (2009) Do managers withhold bad news? Journal of Accounting Research 47(1): 241-274.

KPMG (2005) Introduction to IFRS: Analysts Survey Research. KPMG IFRG Ltd.

Lang M and Lundholm R (1996) Corporate disclosure policy and analyst behavior. Accounting Review 71(4): 467-492.

Matsumoto D, Pronk M and Roelofsen E (2011) What makes conference calls useful? The information content of managers' presentations and analysts' discussion sessions. The Accounting Review 86(4): 1383-1414.

Meek G, Roberts C and Gray S (1995) Factors influencing voluntary annual report disclosures by US, UK and continental European multinational corporations. Journal of International Business Studies 26(3): 555-572.

Ohlson J (1995) Earnings book values and dividends in equity valuation. Contemporary Accounting Research 11(2): 661-687. 
Palmer P (2008) Disclosure of the impacts if adopting Australian equivalents of International Financial Reporting Standards. Accounting and Finance 48(5): 847-870.

Picker R (2006) Too special to go global? Too small to be special? An insight into Australia's decision to adopt IFRS and the consequences for its own standard setting and application. In: Godfrey JM and Chalmers K (eds) Globalisation of Accounting Standards. Edward Elgar Cheltenham pp.98-109.

PricewaterhouseCoopers (PwC) (2006) IFRS: The European Investors' View. PWC London February.

Securities and Exchange Commission (SEC) (2011) Work Plan for the Consideration of Incorporating International Financial Reporting Standards into the Financial Reporting System for U.S Issuers: An Analysis of IFRS in Practice November Norwalk Connecticut. Available at: http://www.sec.gov/spotlight/globalaccountingstandards/ifrs-work-planpaper-111611-practice.pdf.

Skinner DJ (1994) Why firms voluntarily disclose bad news. Journal of Accounting Research 32(1): 38-60.

Skinner DJ (1997) Earnings disclosures and stockholder lawsuits. Journal of Accounting and Economics 23(3): 249-282.

Soffer L, Thiagarajan S and Walther B (2000) Earnings preannouncement strategies. Review of Accounting Studies 5(1): 5-26

Tarca A, Street D and Aerts W (2011) Factors affecting MD\&A disclosures by SEC registrants: Views of practitioners. Journal of International Accounting Auditing and Taxation 20(1): 45-59. 
Table 1 Summary statistics for disclosure scores

\begin{tabular}{|c|c|c|c|c|c|}
\hline & Mean & Median & Std & Min & Max \\
\hline \multicolumn{6}{|c|}{ Panel A: Pre-transition $(\mathrm{n}=150)$} \\
\hline Peform $_{F S}$ & 3 & 2 & 3 & 0 & 14 \\
\hline Position $_{F S}$ & 8 & 8 & 8 & 0 & 34 \\
\hline Comments $_{F S}$ & 3 & 3 & 3 & 0 & 14 \\
\hline $\operatorname{Total}_{F S}$ & 14 & 13 & 12 & 0 & 47 \\
\hline Qualitative $_{F S}$ & 14 & 12 & 12 & 0 & 47 \\
\hline Quantitative $_{F S}$ & 0 & 0 & 1 & 0 & 9 \\
\hline KeyItems $F S$ & 4 & 4 & 4 & 0 & 14 \\
\hline \multicolumn{6}{|c|}{ Panel B: Transition $(n=150)$} \\
\hline Peform $_{F S}$ & 12 & 10 & 9 & 0 & 44 \\
\hline Position $_{F S}$ & 42 & 34 & 36 & 0 & 211 \\
\hline Comments $_{F S}$ & 6 & 6 & 3 & 0 & 18 \\
\hline Total $_{F S}$ & 60 & 48 & 45 & 0 & 248 \\
\hline Qualitative $_{F S}$ & 38 & 32 & 25 & 0 & 137 \\
\hline Quantitative $_{F S}$ & 22 & 18 & 21 & 0 & 111 \\
\hline KeyItems $F S$ & 12 & 10 & 10 & 0 & 55 \\
\hline \multicolumn{6}{|c|}{ Panel C: Adoption ( $\mathrm{n}=150)$} \\
\hline Peform $_{F S}$ & 18 & 15 & 13 & 0 & 61 \\
\hline Position $_{F S}$ & 74 & 60 & 59 & 0 & 354 \\
\hline Comments $_{F S}$ & 8 & 8 & 3 & 0 & 17 \\
\hline Total $_{F S}$ & 100 & 84 & 69 & 3 & 417 \\
\hline Qualitative $_{F S}$ & 57 & 47 & 39 & 2 & 233 \\
\hline Quantitative $_{F S}$ & 42 & 36 & 32 & 0 & 184 \\
\hline Keyltems $s_{F S}$ & 20 & 17 & 14 & 0 & 97 \\
\hline
\end{tabular}

This table reports the distribution of the disclosure scores calculated using the checklist in the Appendix 1. Scores reflect one point for every time a checklist item is discussed by the firm (qualitative disclosure) with an additional one point for providing quantitative disclosure as well in the year end financial statements. Only disclosure about the impact of adoption of IFRS is coded. Perform $_{F S}$ refers to disclosure about impact on financial performance, Position $F S$ refers to disclosure about impact on financial position, and Comments $_{F S}$ refers to the IFRS comments. Total ${ }_{F S}$ is total amount of IFRS impact disclosure. Qualitative $F_{F S}$ disclosures are descriptive statements of fact or opinion that do not include numerical estimation. Quantitative $E_{F S}$ disclosures are narrative statements that include numerical estimation. KeyItems $s_{F S}$ are IFRS impact disclosure in the financial statements about key items (financial instruments, share-based payment, employee entitlements, impairment, intangible assets and tax effects). Pre-transition is the financial year prior to IFRS adoption; Transition is the financial year when IFRS comparative data was prepared and reported at financial year end; Adoption is the first full year of IFRS adoption. 
Table 2 Summary statistics for firm announcements

\begin{tabular}{lcrrrrr}
\hline & N & Mean & Median & Std & Min & Max \\
\hline Panel A: Transition & & & & & & \\
Number & 338 & & & & & \\
Count & 150 & 2 & 2 & 3 & 0 & 19 \\
Lag & 112 & 71 & 66 & 24 & 25 & 162 \\
Perform $_{C A}$ & 150 & 4 & 3 & 4 & 0 & 21 \\
Position $_{C A}$ & 150 & 3 & 2 & 4 & 0 & 18 \\
Comments $_{C A}$ & 150 & 4 & 2 & 5 & 0 & 43 \\
Qualitative $_{C A}$ & 150 & 7 & 5 & 8 & 0 & 51 \\
Quantitative $_{C A}$ & 150 & 2 & 2 & 3 & 0 & 21 \\
Total $_{C A}$ & 150 & 11 & 7 & 13 & 0 & 81
\end{tabular}

Panel B: Adoption

$\begin{array}{lrrrrrr}\text { Number } & 328 & & & & & \\ \text { Count } & 150 & 2 & 1 & 3 & 0 & 17 \\ \text { Lag } & 103 & 84 & 66 & 52 & 23 & 238 \\ \text { Perform }_{C A} & 150 & 3 & 1 & 7 & 0 & 47 \\ \text { Position }_{C A} & 150 & 2 & 0 & 3 & 0 & 18 \\ \text { Comments }_{C A} & 150 & 2 & 1 & 4 & 0 & 29 \\ \text { Qualitative }_{C A} & 150 & 3 & 2 & 5 & 0 & 31 \\ \text { Quantitative }_{C A} & 150 & 2 & 1 & 4 & 0 & 25 \\ \text { Total }_{C A} & 150 & 7 & 3 & 12 & 0 & 94\end{array}$

This table reports the distribution of the disclosure scores calculated using the checklist in the Appendix 2. Scores reflect one point for every time a checklist item is discussed by the firm. Only disclosure about the impact of adoption of IFRS is coded (excluding disclosure in the financial statements, which is coded separately, see Table 1 and Appendix 1). Number is the number of firm announcements in the year. Count is the number of firm announcements per firm. Lag is the number of days between financial year end and announcement date ( $\mathrm{n}<150$ because not all firms make announcements). Perform ${ }_{C A}$ refers to disclosure about impact on financial performance, Position ${ }_{C A}$ refers to disclosure about impact on financial position, and Comments $_{C A}$ refers to the IFRS comments. Qualitative $_{C A}$ disclosures are descriptive statements of fact or opinion that do not include numerical estimation. Quantitative $C_{C A}$ disclosures are narrative statements that include numerical estimation. Total $_{C A}$ is the total amount of IFRS impact disclosure. Transition is the financial year when IFRS comparative data was prepared and reported at financial year end; Adoption is the first full year of IFRS use. 
Table 3 Summary statistics for independent variables

\begin{tabular}{lcccccc}
\hline & $\mathrm{n}$ & Mean/Proportion & Median & Max & Min & Std \\
\hline & & & & & & \\
$\Delta$ Earn $_{T T}$ & 146 & 0.004 & 0.003 & 0.056 & -0.049 & 0.015 \\
$\Delta$ Equity $_{T T}$ & 146 & -0.032 & -0.013 & 0.200 & -0.267 & 0.067 \\
$\Delta$ Earn $_{T A}$ & 146 & 0.012 & 0.007 & 0.175 & -0.150 & 0.052 \\
$\Delta$ Equity $_{T A}$ & 146 & 0.078 & 0.043 & 0.787 & -0.430 & 0.165 \\
Size & 450 & 21.357 & 21.153 & 25.882 & 18.457 & 1.405 \\
Analyst & 450 & 7 & 7 & 11 & 2 & 2.066 \\
Leverage $_{\text {Issues }}$ & 450 & 0.533 & 0.512 & 1.463 & 0.050 & 0.202 \\
& 450 & 0.049 & 0.003 & 4.029 & -0.035 & 0.218 \\
Loss & & & & & & \\
Finance & 450 & 0.058 & & & & \\
Mining & 450 & 0.207 & & & & \\
ForList & 450 & 0.100 & & & & \\
\hline
\end{tabular}

This table reports the distribution of the independent variables. $\Delta E q u i t y_{T T}$ refers to the change in the shareholders' equity as at the transition year end as a result of IFRS adoption. $\triangle E a r n_{T T}$ refers to the change in the net profit after tax at the transition year end as a result of IFRS adoption. $\triangle E$ quity $_{T A}$ refers to the change in the reported shareholders' equity between the transition and adoption years. $\triangle \operatorname{Earn}_{T A}$ refers to the change in the reported net profit after tax between the transition and adoption years. The variable Size is the natural logarithm of the market capitalization, Analysts refers to the number of analysts following the firm, Leverage is the ratio of total liability to total assets and Issues is the ratio of total proceeds from issues to market value of equity. Loss is a dummy variable that takes the value 1 if the firm has a negative net profit after tax, Finance (Mining) is an industry dummy variable that takes the value 1 if the firm is in the financial services (Mining) sector, and 0 otherwise. ForList is a dummy variable that takes the value 1 if the firm is traded on a foreign exchange, and 0 otherwise. 
Table 4 Correlation table

\begin{tabular}{|c|c|c|c|c|c|c|c|c|c|c|c|c|c|}
\hline & Total $_{F S}$ & Peform $_{F S}$ & Position $_{F S}$ & Total $_{C A}$ & Perform $_{C A}$ & Position $_{C A}$ & $\Delta \operatorname{Earn}_{T T}$ & $\Delta$ Equity $_{T T}$ & $\Delta \operatorname{Earn}_{T A}$ & $\Delta$ Equity $_{T A}$ & Size & Analyst & Leverage \\
\hline Peform $_{F S}$ & $0.794 *$ & & & & & & & & & & & & \\
\hline Position $_{F S}$ & $0.990 *$ & $0.708^{*}$ & & & & & & & & & & & \\
\hline Total $_{C A}$ & $0.338^{*}$ & $0.178^{*}$ & $0.352 *$ & & & & & & & & & & \\
\hline Perform $_{C A}$ & $0.344^{*}$ & $0.217^{*}$ & $0.353^{*}$ & $0.926^{*}$ & & & & & & & & & \\
\hline Position $_{C A}$ & $0.292 *$ & $0.143^{*}$ & $0.307^{*}$ & $0.923^{*}$ & $0.777^{*}$ & & & & & & & & \\
\hline$\Delta \operatorname{Earn}_{T T}$ & -0.091 & -0.112 & -0.088 & -0.017 & -0.010 & 0.012 & & & & & & & \\
\hline$\Delta$ Equity $_{T T}$ & 0.061 & 0.075 & 0.046 & 0.026 & 0.024 & -0.001 & $0.139 *$ & & & & & & \\
\hline$\Delta \operatorname{Earn}_{T A}$ & $-0.127 *$ & $-0.127 *$ & $-0.124 *$ & -0.061 & -0.043 & -0.059 & $-0.148 *$ & -0.064 & & & & & \\
\hline$\Delta$ Equity $_{T A}$ & $-0.141^{*}$ & -0.103 & $-0.141 *$ & -0.074 & -0.047 & -0.054 & 0.076 & -0.044 & $0.361 *$ & & & & \\
\hline Size & $0.422 *$ & $0.303^{*}$ & $0.418^{*}$ & $0.496^{*}$ & $0.458^{*}$ & $0.430^{*}$ & -0.037 & -0.023 & 0.102 & 0.033 & & & \\
\hline Analyst & $0.203^{*}$ & $0.144^{*}$ & $0.207^{*}$ & $0.383^{*}$ & $0.337 *$ & $0.375^{*}$ & $-0.126^{*}$ & $-0.136^{*}$ & 0.071 & -0.031 & $0.573^{*}$ & & \\
\hline Leverage & $0.428^{*}$ & $0.305^{*}$ & $0.431 *$ & $0.344^{*}$ & $0.329 *$ & $0.309 *$ & $-0.174^{*}$ & 0.079 & $-0.185^{*}$ & $-0.320 *$ & $0.317^{*}$ & $0.253^{*}$ & \\
\hline Issues & 0.021 & 0.004 & 0.022 & 0.050 & 0.052 & 0.070 & 0.006 & -0.002 & -0.004 & 0.027 & -0.035 & 0.086 & $0.126^{*}$ \\
\hline
\end{tabular}

Perform $_{F S}$ refers to disclosure about impact on financial performance, Position $F S$ refers to disclosure about impact on financial position, and Total FS $_{\text {im }}$ total amount of IFRS impact disclosure. Perform PA $_{\text {refers to disclosure about impact on financial performance, Position }}$ PA refers to disclosure about impact on financial position, and Total $_{C A}=$ total amount of IFRS impact disclosure. $\triangle E$ quity $_{T T}$ refers to the change in the shareholders' equity as at the transition year end as a result of IFRS adoption. $\triangle E a r n_{T T}$ refers to the change in the net profit after tax at the transition year end as a result of IFRS adoption. $\Delta E q u i t y_{T A}$ refers to the change in the reported shareholders' equity between the transition and adoption years. $\triangle$ Earn $_{T A}$ refers to the change in the reported net profit after tax between the transition and adoption years. The variable Size is the natural logarithm of the market capitalization, Analysts refers to the number of analysts following the firm, Leverage is the ratio of total liability to total assets and Issues is the ratio of total proceeds from issues to market value of equity.

* indicates significance at $5 \%$ level. 
Table 5 Regression results - financial statement disclosure

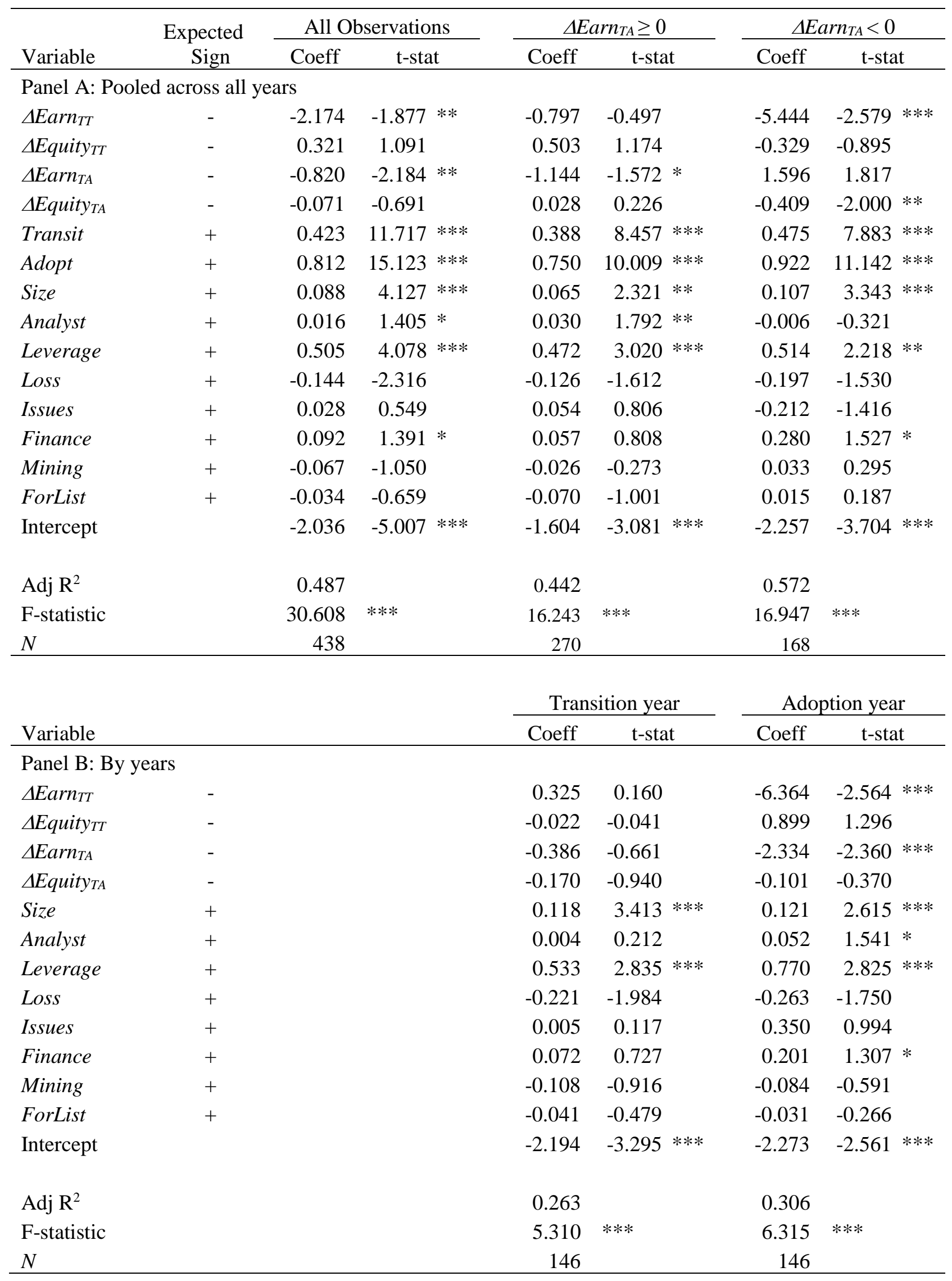


This table reports regression models estimated using equation (1) for financial statement disclosure scores in total. Panel A reports the results for models using the pooled sample comprising observations from all years. Panel B reports the results for the models for the transition and adoption years. $\Delta E$ quity $_{T A}$ refers to the difference in the reported shareholders' equity between transition and adoption year. $\Delta E a r n_{T A}$ is the difference in earnings between transition and adoption year. $\Delta E$ Euity $_{T T}$ refers to the change in the shareholders' equity as at the transition year end as a result of IFRS adoption. $\triangle E a r n_{T T}$ refers to the change in the net profit after tax at the transition year end as a result of IFRS adoption. All independent variables (other than the intercept term) are predicted to have a positive relationship with disclosure. Adopt is a dummy variable that takes the value 1 if the observation is drawn from the adoption year, and 0 otherwise. Transit is a dummy variable that takes the value 1 if the observation is drawn from the transition year, and 0 otherwise. The variable Size is the natural logarithm of the market capitalization, Analysts refers to the number of analysts following the firm, Leverage is the ratio of total liability to total assets and Issues is the ratio of total proceeds from issues to market value of equity. Loss is a dummy variable that takes the value 1 if the firm has a negative net profit after tax and 0 otherwise, Finance (Mining) is an industry dummy variable that takes the value 1 if the firm is in the financial services (Mining) sector, and 0 otherwise. ForList is a dummy variable that takes the value 1 if the firm is traded on a foreign exchange, and 0 otherwise.

$* * *, * *, *$ indicates significance at the $1 \%, 5 \%$ and $10 \%$, respectively, using a 1-tailed test when the predicted direction is indicated and 2 -tailed test otherwise. 
Table 6 Regression results - disclosure in firm announcements

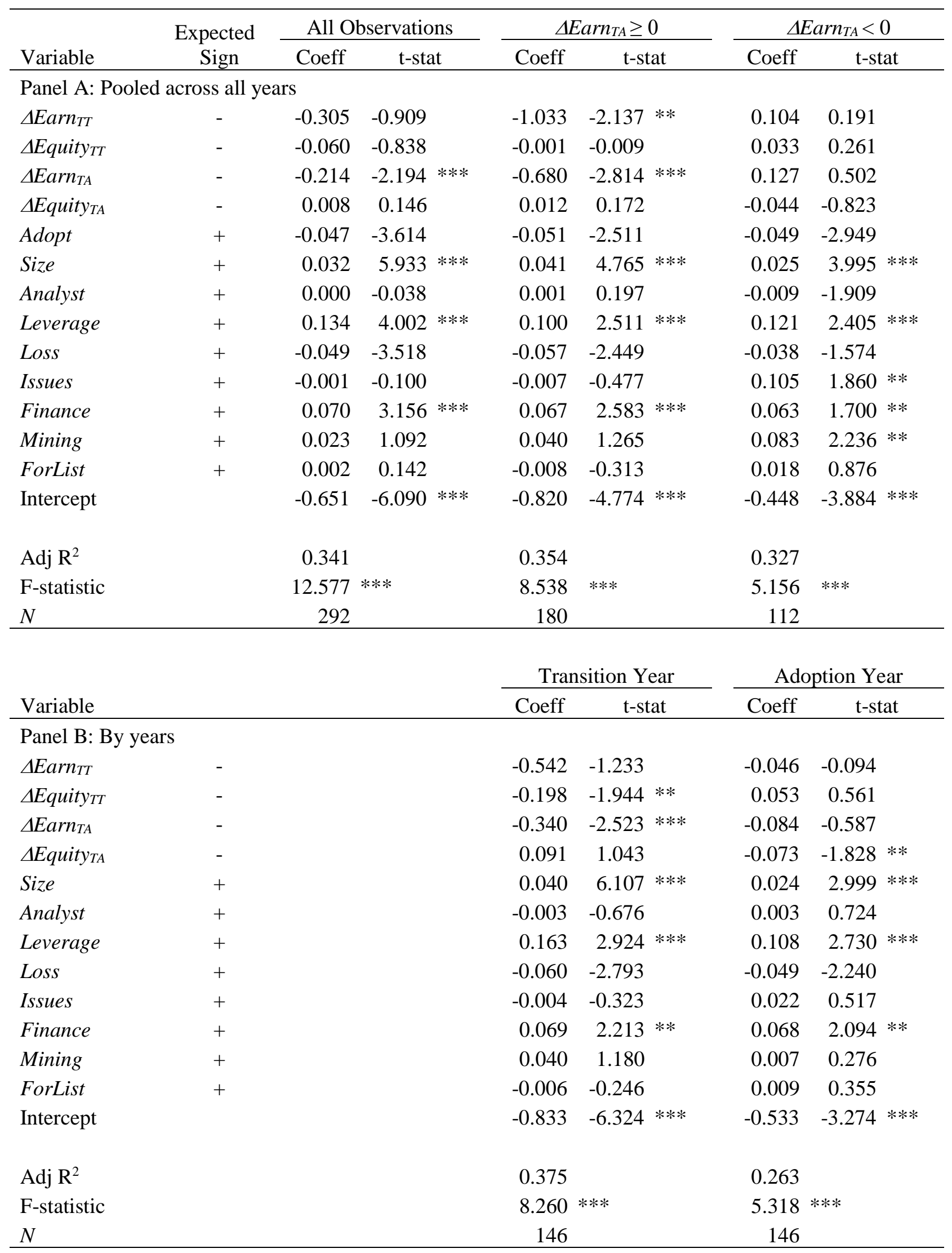


This table reports regression models estimated using equation (1) for firm announcement disclosure scores in total. Panel A reports the results for models using the pooled sample comprising observations from all years. Panel B reports the results for the models for the transition and adoption years. $\Delta E$ quity $_{T A}$ refers to the difference in the reported shareholders' equity between transition and adoption year. $\Delta E a r n_{T A}$ is the difference in earnings between transition and adoption year. $\Delta E$ quity $_{T T}$ refers to the change in the shareholders' equity as at the transition year end as a result of IFRS adoption. $\triangle E a r n_{T T}$ refers to the change in the net profit after tax at the transition year end as a result of IFRS adoption. All independent variables (other than the intercept term) are predicted to have a positive relationship with disclosure. Adopt is a dummy variable that takes the value 1 if the observation is drawn from the adoption year, and 0 otherwise. Transit is a dummy variable that takes the value 1 if the observation is drawn from the transition year, and 0 otherwise. The variable Size is the natural logarithm of the market capitalization, Analysts refers to the number of analysts following the firm, Leverage is the ratio of total liability to total assets and Issues is the ratio of total proceeds from issues to market value of equity. Loss is a dummy variable that takes the value 1 if the firm has a negative net profit after tax and 0 otherwise, Finance (Mining) is an industry dummy variable that takes the value 1 if the firm is in the financial services (Mining) sector, and 0 otherwise. ForList is a dummy variable that takes the value 1 if the firm is traded on a regulated US exchange, and 0 otherwise.

$* * *, * *, *$ indicates significance at the $1 \%, 5 \%$ and $10 \%$, respectively, using a 1 -tailed test when the predicted direction is indicated and 2 -tailed test otherwise. 


\section{Table 7 Regression results - disclosure effect in price regression models}

\begin{tabular}{|c|c|c|c|c|c|c|c|c|c|c|c|c|c|c|c|}
\hline & & & & \multicolumn{6}{|c|}{ Financial statements disclosure } & \multicolumn{6}{|c|}{ Company announcements disclosure } \\
\hline & \multicolumn{3}{|c|}{ (A) } & \multicolumn{3}{|c|}{$\begin{array}{c}\text { Positive residuals } \\
\text { (B) }\end{array}$} & \multicolumn{3}{|c|}{$\begin{array}{c}\text { Negative residuals } \\
\text { (C) }\end{array}$} & \multicolumn{3}{|c|}{$\begin{array}{c}\text { Positive residuals } \\
\text { (D) }\end{array}$} & \multicolumn{3}{|c|}{$\begin{array}{c}\text { Negative residuals } \\
(\mathrm{E})\end{array}$} \\
\hline & Coeff & \multicolumn{2}{|l|}{ t-stat } & Coeff & \multicolumn{2}{|l|}{ t-stat } & Coeff & \multicolumn{2}{|l|}{ t-stat } & Coeff & \multicolumn{2}{|l|}{ t-stat } & Coeff & \multicolumn{2}{|l|}{ t-stat } \\
\hline$B V E$ & 0.451 & 1.197 & & -0.309 & -0.412 & & 0.936 & 2.485 & $* *$ & -0.133 & -0.195 & & 0.989 & 3.083 & $* * *$ \\
\hline$N I$ & 11.624 & 4.616 & $* * *$ & 16.432 & 3.781 & $* * *$ & 7.975 & 3.375 & $* * *$ & 14.949 & 3.578 & $* * *$ & 9.779 & 3.315 & *** \\
\hline$\Delta \operatorname{Earn}_{T T}^{\prime}$ & 5.015 & 1.904 & $* *$ & 8.888 & 2.305 & ** & 9.560 & 1.052 & & 6.779 & 1.714 & $* *$ & 3.494 & 0.402 & \\
\hline$\Delta$ Equity $_{T T}^{\prime}$ & -0.480 & -1.694 & $* *$ & -0.374 & -1.458 & & -0.293 & -0.353 & & 0.277 & 0.712 & & -0.901 & -1.251 & \\
\hline Intercept & 1.331 & 2.490 & $* *$ & 1.896 & 1.909 & * & 1.170 & 1.826 & * & 1.730 & 1.998 & $*$ & 0.844 & 0.937 & \\
\hline $\operatorname{Adj} R^{2}$ & & 0.781 & & & 0.829 & & & 0.723 & & & 0.821 & & & 0.752 & \\
\hline $\mathrm{N}$ & & 145 & & & 61 & & & 84 & & & 66 & & & 79 & \\
\hline
\end{tabular}

The dependent variable is share price measured three months after year end. BVE is a firm's book value of equity at year end. NI is net profit. $\Delta E q u i t y T T$ refers to the change in shareholders' equity at the transition year end as a result of IFRS adoption. $\triangle E_{a r n}{ }_{T T}$ refers to the change in net profit after tax at the transition year end as a result of IFRS adoption. All variables are deflated by number of shares at year end. Panel A shows models for the full sample. Panel B (Panel C) shows models for the subgroup of firms that have positive (negative) residuals in the fitted Equation 1 when the dependent variable is total financial statement disclosure. Panel D (Panel E) shows models for the subgroup of firms that have positive (negative) residuals in the fitted Equation 1 when the dependent variable is total firm announcement disclosure.

$* * *, * *, *$ indicates significance at the $1 \%, 5 \%$ and $10 \%$, respectively, using a 1-tailed test when the predicted direction is indicated and 2 -tailed test otherwise. 
Appendix 1 Checklist: IFRS disclosure in the financial statements

\begin{tabular}{|c|c|c|}
\hline Category & $\begin{array}{l}\text { Sub- } \\
\text { item }\end{array}$ & Item \\
\hline \multicolumn{3}{|c|}{ Group A Financial performance } \\
\hline 1 & 0 & Revenue - total \\
\hline 2 & 0 & Expenses - total \\
\hline 2 & 1 & Share based compensation expense \\
\hline 2 & 2 & Defined benefit plan expense (defined contribution, actuarial gain/loss) \\
\hline 2 & 3 & Impairment \\
\hline 2 & 4 & Amortisation \\
\hline 2 & 5 & Depreciation \\
\hline 2 & 6 & Leases expense \\
\hline 2 & 7 & R\&D expense \\
\hline 2 & 8 & Administration and branch expenses \\
\hline 2 & 9 & Foreign currency (gain)/loss \\
\hline 2 & 10 & Financial instruments (gain)/loss \\
\hline 2 & 11 & Cost of sales \\
\hline 2 & 12 & Rental expense \\
\hline 2 & 13 & Development expense \\
\hline 2 & 14 & Restoration expense \\
\hline 2 & 16 & Operating expense \\
\hline 2 & 17 & Other expenses \\
\hline 3 & 1 & Profit associates (equity accounting, income investments in associates) \\
\hline 3 & 2 & Profit joint ventures \\
\hline 3 & 3 & Operating profit before tax \\
\hline 3 & 4 & Tax \\
\hline 3 & 5 & Discontinued operations \\
\hline 3 & 6 & Net profit after tax \\
\hline 4 & 1 & EPS \\
\hline 4 & 2 & ROE \\
\hline \multicolumn{3}{|c|}{ Group B Financial position } \\
\hline 5 & 0 & Assets - total \\
\hline 5 & 1 & Assets - financial instruments \\
\hline 5 & 2 & Assets - defined benefit plan and employee share plan assets \\
\hline 5 & 3 & Assets - intangibles, goodwill, R\&D, E\&E \\
\hline 6 & 0 & Liabilities - total \\
\hline 6 & 1 & Liabilities - financial instruments \\
\hline 6 & 2 & Liabilities - defined benefit plan and employee share plan liabilities \\
\hline 7 & 0 & Equity - total \\
\hline 7 & 1 & Equity - foreign currency reserve \\
\hline 7 & 2 & Equity - financial instruments reserve \\
\hline 7 & 3 & Equity - retained earnings \\
\hline 8 & 1 & Net Assets \\
\hline 8 & 2 & Net Debt \\
\hline 8 & 3 & Net Equity \\
\hline \multicolumn{3}{|c|}{ Group C IFRS comments } \\
\hline 9 & 0 & Impact statements \\
\hline 10 & 0 & Volatility statements \\
\hline 11 & 1 & Plan \\
\hline 11 & 2 & Process \\
\hline 11 & 3 & Comparability (international) \\
\hline 11 & 4 & External advice \\
\hline 11 & 5 & Uncertainty \\
\hline 11 & 6 & Miscellaneous \\
\hline \multicolumn{3}{|c|}{$\begin{array}{l}\text { All items of disclosure in the relevant documents are scored as } 1 \text { on the checklist, thus providing a } \\
\text { measure of amount of disclosure, by category. Items scored } 1 \text { for qualitative disclosure with an } \\
\text { additional } 1 \text { for quantitative disclosure. }\end{array}$} \\
\hline
\end{tabular}


Appendix 2 Checklist: IFRS disclosure in the firm announcements

\begin{tabular}{|c|c|}
\hline Points & Group A Financial performance \\
\hline & Discussion of \\
\hline 1 & Overall impact (qualitative) \\
\hline 1 & One element \\
\hline 1 & Two or more elements \\
\hline 1 & Quantify impact \\
\hline 1 & Impact on segments \\
\hline 1 & Proforma measures \\
\hline 1 & Ratios overall \\
\hline 1 & Ratios one element \\
\hline 1 & Ratios two or more elements \\
\hline 1 & Ratios segments \\
\hline \multicolumn{2}{|l|}{$\operatorname{Max}=10$} \\
\hline & Group B Financial position \\
\hline & Discussion of \\
\hline 1 & Overall impact (qualitative) \\
\hline 1 & One element \\
\hline 1 & Two or more elements \\
\hline 1 & Quantify impact \\
\hline 1 & Impact on segments \\
\hline 1 & Proforma measures \\
\hline \multicolumn{2}{|l|}{$\operatorname{Max}=6$} \\
\hline & Group C Comments impact of IFRS \\
\hline & Discussion of \\
\hline 1 & Impact (qualitative) \\
\hline 1 & Impact (quantitative) \\
\hline 1 & Volatility (qualitative) \\
\hline 1 & Volatility (quantitative) \\
\hline 1 & Other (qualitative) \\
\hline 1 & Other (quantitative) \\
\hline 1 & IFRS comment \\
\hline 1 & Alternative measures \\
\hline \multicolumn{2}{|l|}{$\operatorname{Max}=8$} \\
\hline TOTAL $=24$ & \\
\hline \multicolumn{2}{|c|}{$\begin{array}{l}\text { All firm announcements lodged with the ASX containing information about the impact of IFRS } \\
\text { (excluding the financial statements) were coded using the above checklist. Firms were given one } \\
\text { point for each item in the checklist, to a maximum of } 10 \text { points for Group A (Financial Performance), } \\
6 \text { points for Group B (Financial Position) and } 8 \text { points for Group C (IFRS Comments) giving a } \\
\text { maximum overall score of } 24 \text {. }\end{array}$} \\
\hline
\end{tabular}

